\title{
Translation of Multi-Word Verbs in English Cookbook into Indonesian
}

\author{
Kadek Ayu Ekasani ${ }^{1}$, Ida Bagus Putra Yadnya ${ }^{2}$, Ketut Artawa² \& Ni Luh Ketut Mas Indrawati ${ }^{2}$ \\ ${ }^{1}$ Sekolah Tinggi Pariwisata Bali Internasional, Indonesia \\ ${ }^{2}$ Udayana University, Indonesia \\ Correspondence: Kadek Ayu Ekasani, Jl. Kecak No.12 Denpasar-Bali, Indonesia. Tel: 62-878-6003-1317. E-mail: \\ ekasani@stpbi.ac.id
}

Received: June 4, 2019; Accepted: June 16, 2019; Published: June 25, 2019

\begin{abstract}
This paper examines translation of multi-word verbs in English cookbook into Indonesian. This study emphasises on the analysis of the translations of multi-word verbs in English cookbook and its translation into Indonesian. The classification and the meaning of phrasal verbs are proposed by Quirk (1985). The research is descriptive qualitative. Methods of collecting data are observation and documentation. The data source was taken from English cookbook entitled The Essential Book of Sauces \& Dressings from Murdoch Books published by Periplus, Singapore and its translation into Indonesian entitled Saus dan Dressing yang Esensial by Hadyana P. published by Periplus, Indonesia. The study shows that there are three types of multi-word verbs found in data source. They are phrasal verbs, prepositional verbs and phrasal prepositional verbs.
\end{abstract}

Keywords: translation, multi-word verbs, phrasal verbs, prepositional verbs, phrasal prepositional verbs, cookbook

\section{Introduction}

Translation is one of the applied linguistics that transfer the meaning from the source language to the target language. Bell states that the expression from source language into the target language preserving semantic and stylistic equivalences (Bell, 1991, p. 5). Larson (1984, p. 3) defines translation as the transfer of meaning from the source language into the target language through three-step approach: 1) studying the lexicon, grammatical structure, communication situation, and cultural context of the source language text;2) analyzing the source language text to find its meaning; and 3) revealing the same meaning by using the appropriate lexicon and grammatical structure in the target language. Bell affirmed a similar interpretation of translation to Catford, i.e. translation as a form of expression of a language in another language as the target language, by putting forward semantics and equivalents. Based on the definitions of translation above, the understanding of multi-word verbs is really important for the translator to make the closest equivalence from the data source.

According to Greenbaum (2002, p. 64), furthermore, multi-word verbs are a verb with its particles that has one meaning. Multi-word verbs are usually used by all native English speakers in daily communication. The verbs can be easily used to get the closest relationship with other people through expressing vivid, emotional and frequently slangy points in daily activities. However, it will be different for non-English speakers when interpreting the verbs. Most of the English literatures use multi-word verbs in the sentence or explanation to make the sentence more idiomatic. The data source that is used in this research is English-Indonesian cookbooks. The previous researchers who have similar focus of discussion are Eni, Artawa, Udayana (2017) and Santika, Putri, Suastini (2017). Their researches discuss about one type of multi-word verbs, that is, phrasal verbs. The results of both researches show that most of the phrasal verbs are included into transitive separable verbs and from the three categories of phrasal verbs; they were translated mostly into transitive verbs. Meanwhile, the meanings of phrasal verbs in SL determine the suitable equivalents for the phrasal verbs in TL since there were variants equivalents given in the translations.

This research emphasises the analysis of multi-word verbs in an English cookbook and its translation into Indonesian. This research will help Indonesian students in food production major to understand the use of multiword verbs in the process of cooking from their English cookbooks. Mostly they used to make International dishes instead of Indonesian ones. So, the understanding of multi-word verbs is really needed for the Indonesian students when they have to make the dish from the English cookbook and the results are as expected. 


\section{Literature Review}

\subsection{Theory of Translation}

Translation relates to transfer the meaning from the source text into the target text and it is one part of applied linguistics. Catford in Jayantini (2016, p. 5) implies that translation cannot be separated from the existence of language with its elements like classification of language levels, language rule, and language phonology. Catford confirms that translation is the replacement of textual material in one language by equivalent textual material in another language. Equivalent in translation activity means to meet the equality in meaning and importance. By 'meaning' it means the idea and message are compatible while 'importance' relates to the impact of the translation product (Jayantini, 2016, p. 13). This is clearly stated by Nida and Taber in Jayantini (2016, p. 5) that translation contains the producing in the receptor language the closest natural equivalent of the source language message; first in the term of meaning and secondly in the term of style.

\subsection{Multi-Word Verbs}

Greenbaum (2002, p. 64) states that multi-word verbs are a verb combined with other words and become a single verb that has one meaning. Multi-word verb is defined as a verb "followed by a morphologically invariable particle, which functions with the verb as a single grammatical unit" and "behaves to some extent either lexically or syntactically as a single verb" (Quirk, 1985, p. 1150). Multi-word verb contains one or two particles. The particles can be a form of prepositional or adverbial particles. There are three types of multi-word verbs; they are phrasal verbs, prepositional verbs, and phrasal-prepositional verbs.

\subsubsection{Phrasal Verbs}

Phrasal verb is a combination between the verb and adverb particle. Downing $(2006$, p. 60) states that phrasal verb is a lexical verb combined with an adverbial particle (p) (get up, switch on/off, take back, sit down). Phrasal verb can be intransitive (does not require an object, like in the sentence What time do you usually get up in the morning?) or transitive (requires an object, She switched off the light). Quirk (1985, p. 1150) states that "the words which follow the lexical verb in expressions like drink up, dispose of, and get away with are morphologically invariable, and will be given the neutral designation particles. They actually belong to two distinct but overlapping categories, that of prepositions and that of spatial adverbs (though such adverbs are not necessarily used with spatial meaning)". There are three groups of particles, they are:

a) against, among, as, at, besides, for, from, into, like, of, onto, upon, with, etc.

b) about, above, across, after, along, around, by, down, in, off, on, out (AmE), over, past, round, through, under, up, etc.

c) aback, ahead, apart, aside, astray, away, back, forward(s), home, in front, on top, out (BrE), together, etc.

Those particles can be categorized as preposition (a), spatial adverbs (c), or can be either prepositions or spatial adverbs (b) (Quirk, 1985, p. 1151).

Coghill (2003, p. 114) claims that there are two categories of phrasal verbs; they are separable phrasal verbs and inseparable phrasal verb. Separable phrasal verbs can be separated by their object, meanwhile inseparable cannot be separated by their object because that will make the sentence grammatically incorrect. There are two conditions of the object in separable phrasal verb: first, if the object is a noun, it can usually be placed between the verb and the particle or after the particle; second, if the object is a pronoun, it must be placed between the verb and the particle.

\section{She put on her coat.}

\section{She put her coat on.}

\section{She could not deal with the situation.}

*She could not deal the situation with. (Coghill, 2003:114)

\subsubsection{Prepositional Verbs}

"Prepositional verb is a combination of a verb and one particle" (Greenbaum, 2002, p. 64). Prepositional verb can be classified as transitive verb because it requires an object after the verb to complete the sentence. Prepositional verbs can be categorized into three, those are: first, the verb is followed by a prepositional object, and the object differs from direct and indirect objects in that a preposition introduces it: My aunt is looking after my brothers. Second, the verb is followed by direct object and prepositional object, where the direct object comes before the particle, and the prepositional object follows the particle: He blamed the accident on the weather. 'The accident' is direct object meanwhile 'the weather' is prepositional object. Third, the verb is followed by indirect object and 
prepositional object: They told us about your success. 'Us' is indirect object and 'your success' is prepositional object. The preposition particles above cannot be moved or even omitted from their position because can change the meaning of the verb.

\subsubsection{Phrasal-prepositional verbs}

Phrasal-prepositional verb is combination between verb and two particles (Greenbaum, 2002, p. 64). There are two types of phrasal-prepositional verbs, which have two particles (an adverb followed by a preposition). The first type has just the prepositional object:

I have been catching up on my reading.

They look down on their neighbours.

The second type has a direct object and a prepositional object:

I have put his problem down to inexperience.

We put him up for election.

\section{Research Method}

\subsection{Data Source}

The data source used in this study is an English cookbook entitled "The Essential Book of Sauces \& Dressings" from Lowery Barbara, published by Periplus, Singapore and its translation into Indonesian entitled Saus dan Dressing yang Esensial by Hadyana P. published by Periplus, Indonesia. This book was chosen as the data source because it was one of cookbooks which were sold in bilingual (the original and its translated version). Besides the procedures of making the food clearly showed the usage of multi-word verbs so it was interested to be analysed in order to find out the form of multi-word verbs and their structure.

\subsection{Method and Technique of Collecting Data}

The data in this study were collected by using the observation and documentation method. The techniques of collecting the data in this study were done in several steps. First, a close reading of the source text was conducted to find out the form of multi-word verbs used in the cookbook. The next step was to find out and highlight the phrases which were classified as phrasal verbs, prepositional verbs, or phrasal-prepositional verbs. The next step was identifying and selecting some English multi-word verbs found in the cookbook and their translation in target texts and choosing the multi-word verbs in the different forms for the data analysis. The last step was typing and coding the data into the computer.

\subsection{Method and Technique of Analysing Data}

The qualitative method was used in analysing the data in this study. There were some steps in analysing the data in this study. First step in analysing the collected data was identifying and categorizing the forms of multi-word verbs based on the theory of multi-word verbs by Quirk (1985). Then the classification of multi-word verbs were analysed based on the types of multi-word verbs' form.

\section{Result and Discussion}

\subsection{Phrasal Verbs}

(4-1) SL : Stir in the chives. (p.5)

\section{TL : Masukkan kucai. (p.5)}

The structure of phrasal verb in the data above consists of a lexical verb (stir) and adverbial particle (in). The adverb 'in' has function to change the meaning of the lexical verb (stir). 'To stir' means to move a spoon or other implement around in (a liquid or other substance) in order to mix it thoroughly. 'In' means expressing movement with the result that someone or something becomes enclosed or surrounded by something else. Meanwhile 'stir in' means to add something to liquid or substance and mix it. The phrasal verb in the data source above can be classified into transitive verb, a verb requires an object. Its translation is also categorized into transitive verb because an object occurs after the verb.

The translation of phrasal verb in the source language is translated into masukkan in the target language. Masukkan means to put something to something else (liquid), and has the closest equivalent to its source language. The message is well-transferred.

(4-2) SL : Stir in $1 / 2$ cup coconut milk. . (p.27)

$$
\text { TL : Tambahkan } 1 / 2 \text { cangkir santan encer. . . (p.27) }
$$


The structure of phrasal verb in the data above consists of a lexical verb (stir) and adverbial particle (in). The phrasal verbs, stir in in (4-1) and (4-2) are similar. It means to move a spoon or other implement around in (a liquid or other substance) in order to mix it thoroughly. The different is from the translation in target language. In (4-2) the translation for the phrasal verb stir in is tambahkan. Tambahkan means to add something to something else and mix it. It also has the closest equivalent with its source language, so the message is also well-transferred.

(4-3) SL : Remove the meat from the roasting pan and set aside. (p.6)

TL : Angkat daging dari loyang panggang, sisihkan. (p.6)

The structure of phrasal verb in the data above consists of a lexical verb (set) and adverbial particle (aside). The purpose of the adverb (aside) is to change the meaning of the verb (set). 'To set' has the meaning to put someone or something in a position. 'Aside' is used for telling someone that what you are mentioning is not as important as what you are going to say next. Meanwhile 'set aside' means to keep or save something from a larger amount or supply in order to use it later for a particular purpose. The phrasal verb in the source language above is categorized into intransitive verb, a verb does not require an object. Its translation is also categorized into intransitive verb because there is no object occurs after the verb.

The phrasal verb in the source language is translated into sisihkan in the target language. The meaning of words set aside above is to keep or save something from a larger amount or supply in order to use it later for a particular purpose which then the closest equivalent from word given above is sisihkan, because these also have the sense of meaning as in the source text.

(4-4) SL : Rinse and drain the peppercorns and set them aside. (p.2)

TL : Cuci dan tiriskan lada, sisihkan. (p.2)

The structure of phrasal verb in the data (4-4) consist of a lexical verb (set) + object (them) + adverbial particle (aside). The difference between phrasal verb in (4-2) and (4-3) are the object placed between verb and particle. So the phrasal verb in (4-3) can be classified as separable phrasal verb.

The translation of phrasal verb in source language is translated into sisihkan in target language. The meaning of phrasal verb in source language has the closest equivalent from its translation in target language.

(4-5) SL : Make up 1 quantity of basic mayonnaise. (p.35)

TL : a. Tambahkan mayones dasar. ... (p.35)

b. Siapkan mayones dasar. (p.35)

In the source language, the structure of phrasal verb consists of a lexical verb (make) + adverbial particle (up). The occurrence of the object after the phrasal verb means that the words make up is included into category of transitive verbs, since it requires an object. Its translations are also categorized as transitive verb because they are followed by objects after the verbs. The meaning of words make up is to prepare or arrange something or to make an amount or a number complete which then the closest equivalents from words given above are tambahkan and siapkan. Tambahkan means to add something to increase the amount or a number complete, while siapkan means to prepare something ready to use.

(4-6) SL : . . can liven up many simple dishes. (p.36)

TL : . . . menambah nikmat berbagai sajian sederhana. (p.36)

The structure of phrasal verb in the data (4-6) consists of a lexical verb (liven) + adverbial particle (up). Liven up means to give something a more interesting appearance, taste, or other quality. The phrasal verb in the data source above can be classified into transitive verb, a verb requires an object. Its translation is also categorized into transitive verb because an object occurs after the verb. The translation of phrasal verb in the source language is translated into menambah nikmat in the target language. The meaning of words liven up above has the closest equivalent with its translation.

(4-7) SL : Fold in the chives and season to taste with salt and pepper. (p.39)

\section{TL: Tambahkan kucai, garam dan lada secukupnya. (p.39)}

The structure of phrasal verb in the data (4-7) consists of a lexical verb (fold) + adverbial particle (in). Fold in means to use a spoon or knife, to add something slowly, and to a mixture gently. The phrasal verb in the sentence above is translated into a transitive verb where there is object after the phrasal verb. The phrasal verb in the source language is translated into tambahkan in the target language. Tambahkan means to add something to something else and it has the closest equivalent with its source text. 
(4-8) SL : ... spice up a wide variety of foods. (p.46)

TL : ... memberi citarasa pada berbagai hidangan. . . (p.46)

The structure of phrasal verb in the data (4-8) consists of a lexical verb (spice) + adverbial particle (up). Spice up means to add spices to food in order to give it a stronger taste. The phrasal verb in the data source above can be classified into transitive verb, a verb requires an object. Meanwhile its translation is categorized into intransitive verb because there is no object occurs after the verb. Pada berbagai hidangan is categorized as an adverbial of place. The translation of the phrasal verb in the source language is memberi citarasa in the target language and also has the closest equivalent with its source text.

\subsection{Prepositional Verbs}

(4-9) SL : Using a metal spoon, fold into the Hollandaise sauce. (p.23)

$\mathrm{TL}$ : Aduk krim dan saus Hollandaise dengan sendok. (p.23)

The structure of prepositional verb in the data (4-9) consists of a lexical verb (fold) + preposition (into). The preposition (into) has function to modify the structure of the verb (fold) so it has different meaning from its original. 'To fold' means to bend a piece of paper or cloth and press one part of it over another part. 'Into' is used for showing movement. Meanwhile 'fold into' means to use a spoon or knife, to add something slowly, and to a mixture gently. The prepositional verb in the source language above is followed by a prepositional object (the Hollandaise sauce).

The translation of the prepositional verb in the source language is aduk in the target language. The meaning of prepositional verbs fold into has the closest equivalent from its translation, aduk.

\subsection{Phrasal-Prepositional Verbs}

(4-10) BS : Make sure the pan does not get too hot or you will end up with scrambled eggs. (hal.22)

BT : Pastikan panci tidak terlalu panas atau Anda akan mendapatkan telur goreng acak. (hal.22)

The structure of phrasal-prepositional verb in the data (4-10) consists of a lexical verb (end) + adverbial particle (up) + preposition (with). The meaning of phrasal-preposition verb (end up with) is to be in a particular place or state after doing something or because of doing it. The phrasal-prepositional verb in the source language above is followed by a prepositional object (scrambled eggs).

The phrasal-prepositional verb is translated into mendapatkan in the target language. The meaning of phrasalprepositional verbs end up with has the closest equivalent from its translation, mendapatkan.

\section{Conclusion}

There are three types of multi-word verbs found in the English cookbook as the data source: they are phrasal verb, prepositional verb, and phrasal-prepositional verb. There are six phrasal verbs found in the data source: they are stir in, set aside, make up, liven up, fold in, spice up; one prepositional verbs: fold into; and one phrasalprepositional verb: end up with. From the transitivity point of view, there are five phrasal verbs categorized as transitive phrasal verbs and there is one phrasal verb categorized as intransitive phrasal verbs. The translation of multi-word verbs is mostly translated into transitive verbs which require objects after the verbs. However, they are included into appropriate translation as the message or the meaning of each multi-word verb is transferred well.

\section{References}

Bell, R. T. (1991). Translation and Translating: Theory and Practice. London: Longman.

Coghill, J., \& Stacy, M. (2003). English Grammar. New York: Univ. Press.

Downing, A., \& Locke, P. (2006). English Grammar A University Course Second edition. New York: Routledge. https://doi.org/10.4324/9780203087640

Eni, N. P. S., Artawa, K., \& Udayana, I. N. (2017). The Analysis of Phrasal Verbs in the Novel "The Hobbit" By J. R. R. Tolkien. Jurnal Humanis, Fakultas Ilmu Budaya Unud, 18, 244-251.

Greenbaum, S., \& Nelson, G. (2002). An Introduction to English Grammar. Second edition. London: Pearson Education Limited.

Hadyana. (2006). Saus dan Dressing yang esensial. Jakarta: Periplus.

Jayantini, S. R. (2016). The Art of Translating Theory and Analysis. Denpasar: Cakra Press.

Larson, M. L. (1984). Meaning-based Translation: A Guide to Cross Language Equivalence. New York: University Press of America. 
Lowery, B., Brodhust, W., Goggin, W., \& Earl, M. (1996). The essential book of sauces and dressings. Singapore: Periplus.

Quirk, R. (1985). A Comprehensive Grammar of the English Language. USA: Longman Inc.

Santika, I Dewa Ayu Devi M., Putri, I Gusti Vina W., \& Suastini, N. W. (2017). Translation of Phrasal Verbs Into Indonesian. Lingual, 9(2), 16-21. https://doi.org/10.31940/jasl.v2i1.804

\section{Copyrights}

Copyright for this article is retained by the author(s), with first publication rights granted to the journal.

This is an open-access article distributed under the terms and conditions of the Creative Commons Attribution license (http://creativecommons.org/licenses/by/4.0/). 